\title{
Effect of Row Spacing, Varieties and Sowing Dates on Growth and Yield of Pigeonpea
}

\author{
Sharanappa Kuri*, H.S. Shivaramu, M.N. Thimmegowda, S.B. Yogananda, \\ S.S. Prakash and Murukannappa \\ Department of Agronomy, College of Agriculture, UAS, GKVK, Bengaluru-65 \\ *Corresponding author
}

\begin{tabular}{|l|}
\hline Ke y w or d s \\
$\begin{array}{l}\text { Varieties, Dates of } \\
\text { sowing, Spacing, } \\
\text { Growth, Yield }\end{array}$ \\
\hline Article Info \\
\hline $\begin{array}{l}\text { Accepted: } \\
\text { 08 July } 2018 \\
\text { Available Online: } \\
\text { 10 August } 2018\end{array}$ \\
\hline \hline
\end{tabular}

A B S T R A C T

Field experiment was conducted during Kharif-2015-16 and 2016-17 at AICRP on Agrometeorology, Gandhi Krishi Vignana Kendra (GKVK), UAS, Bangalore to assess the effect of row spacing, varieties and date of sowing on growth and yield of pigeonpea. Significantly higher growth parameters viz., plant height $(165.4 \mathrm{~cm})$, leaf area index (2.10), leaf area duration (60.34 days) and crop growth rate $\left(2.39 \mathrm{~g} \mathrm{~m}^{-2} \mathrm{day}^{-1}\right)$ and yield parameters (grain: $940 \mathrm{~kg} \mathrm{ha}^{-1}$ and stalk: $4089 \mathrm{~kg} \mathrm{ha}^{-1}$ ) were recorded in narrow row spacing $(60 \mathrm{~cm})$ compared to wider row spacing $(90$ and $120 \mathrm{~cm}$ ). The TTB-7 recorded significantly higher growth viz., plant height $(163.6 \mathrm{~cm})$, no. of branches per plant $(10.4)$, total dry matter accumulation per plant $(65.33 \mathrm{~g})$, leaf area per plant $\left(3429 \mathrm{~cm}^{-2}\right)$, leaf area index (1.81), leaf area duration (50.97 days) and crop growth rate $\left(2.33 \mathrm{~g} \mathrm{~m}^{-2} \mathrm{day}^{-1}\right)$ and yield (grain: $914 \mathrm{~kg} \mathrm{ha}^{-1}$ and stalk: $3427 \mathrm{~kg} \mathrm{ha}^{-1}$ ) compared to BRG-2 variety. Significantly recoded higher growth viz., plant height $(185.2 \mathrm{~cm})$, no. of branches per plant $(10.7)$, total dry matter accumulation per plant $(71.26 \mathrm{~g})$, leaf area per plant $\left(4030 \mathrm{~cm}^{-2}\right)$, leaf area index (2.12), leaf area duration (57.23 days) and crop growth rate $\left(2.66 \mathrm{~g} \mathrm{~m}^{-2}\right.$ day $\left.^{-1}\right)$ and yield (grain: $1149 \mathrm{~kg} \mathrm{ha}^{-1}$ and stalk: $3721 \mathrm{~kg} \mathrm{~h}^{-1}$ ) parameters in May had sown pigeonpea than June and July. Significantly higher grain yield $\left(1284 \mathrm{~kg} \mathrm{ha}^{-1}\right)$ and stalk yield $\left(4980 \mathrm{~kg} \mathrm{ha}^{-1}\right)$ was observed in narrow row spacing $(60 \mathrm{~cm})$ with TTB-7 variety at May month sown crop $\left(S_{1} V_{1} D_{1}\right)$ which was on par with $S_{2} V_{1} D_{1}, S_{1} V_{1} D_{2}$ and $S_{1} V_{2} D_{1}$. Significantly lower grain yield $\left(344 \mathrm{~kg} \mathrm{ha}^{-1}\right)$ was recorded in wider row spacing $(120 \mathrm{~cm})$ with BRG-2 at July sown crop $\left(\mathrm{S}_{3} \mathrm{~V}_{2} \mathrm{D}_{3}\right)$ and lower stalk yield $\left(1932 \mathrm{~kg} \mathrm{ha}^{-1}\right)$ was observed in wider row spacing $(120 \mathrm{~cm})$ with TTB-7 at July month sown crop $\left(\mathrm{S}_{3} \mathrm{~V}_{1} \mathrm{D}_{3}\right)$.

\section{Introduction}

Pigeonpea [Cajanus cajan (L.) Millsp.] is the second most important pulse crop of India after chickpea. In India, it is grown over an area of $0.38 \mathrm{~m}$ ha with a production of $0.33 \mathrm{~m}$ $\mathrm{t}$ and the productivity is $859 \mathrm{~kg} \mathrm{ha}^{-1}$ (Anon., 2016a). It is often grown on marginal lands under rainfed condition and usually intercropped with cereals and sole crop. Besides, fixing atmospheric nitrogen, pigeonpea sheds most of its leaves at maturity and helps to improve the soil organic matter and thus the soil health. The pigeonpea growers face several constraints which come in the way of boosting its productivity. The 
constraints include water stress (drought and water logging), non-availability of suitable varieties, existing varieties having different sowing windows, non-availability of inputs on time, adoption of inappropriate planting geometry and plant population and inadequate transfer of technology. The secret of boosting its yields mainly lies with suitable sowing date, varieties and spacing in pigeonpa. Hence this field study was undertaken.

\section{Materials and Methods}

The experiment was conducted during Kharif2015-16 and 2016-17 at AICRP on Agrometeorology, Gandhi KrishiVignana Kendra (GKVK), Bengaluru. The center is situated in the Eastern Dry zone of Karnataka at $12^{\circ} 58^{\prime}$ North latitude and $77^{\circ} 35^{\prime}$ East longitude with an altitude of $930 \mathrm{~m}$ above the mean sea level.

The soils of GKVK farms belong to Vijayapura series and are classified as Oxichaplustalf. According to FAO classification, the soils are ferric luvisols. Soils are reddish brown laterite derived from gneiss under subtropical semiarid climate. The soil of experimental site was red sandy clay loam in texture.

The study was undertaken in factorial RCBD with three factors which are replicated thrice. The first factor was row spacing $\left(\mathrm{S}_{1}: 60 \mathrm{~cm} \mathrm{x}\right.$ $22.5 \mathrm{~cm}, \mathrm{~S}_{2}: 90 \mathrm{~cm}$ x $22.5 \mathrm{~cm}$ and $\mathrm{S}_{3}: 120 \mathrm{~cm}$ $\mathrm{x} 22.5 \mathrm{~cm})$, second factor was varieties $\left(\mathrm{V}_{1}\right.$ : TTB-7 and $\mathrm{V}_{2}$ : BRG-2) and the third factor was Sowing dates $\left(\mathrm{D}_{1}\right.$ : May, $\mathrm{D}_{2}$ : June and $\mathrm{D}_{3}$ : July).

The observations on growth parameters like plant height, number of branches per plant, and total dry mater accumulation per plant were recorded at harvest. The leaf area, leaf area index, Leaf area duration and crop growth rate were observed at 120 DAS. Grain and stalk yield was calculated based on the yield obtained from each net plot and converted to $\mathrm{kg} \mathrm{ha}^{-1}$ at harvest. The emphasis was given to present the results of pooled data considering the similarity in results of individual years (2015-16 and 2016-17). The data was statistically analyzed by following the method of Gomez and Gomez (1984).

\section{Results and Discussion}

Plant growth is dependent on the rate of accumulation of dry matter. The dry matter accumulation may reflect on the grain yield. The fact is that vegetative part of the plants serve as source, whereas, grains are the sink. The need for the increased crop productivity is an outcome of a series of intermediate interaction of various biological events involving biochemical, physiological and morphological changes which takes place during its development in accordance with the supply of light, water, temperature and nutrients (Donald, 1962).

\section{Effect of row spacing on growth, dry matter accumulation and yield}

The grain and stalk yield of pigeonpea were significantly influenced by row spacing (Table 1). Narrow row spacing $(60 \mathrm{~cm})$ recorded significantly higher grain and stalk yield (940 and $4089 \mathrm{~kg} \mathrm{ha}^{-1}$, respectively) followed by 90 $\mathrm{cm}$ row spacing (918 and $3059 \mathrm{~kg} \mathrm{ha}^{-1}$, respectively) and significantly lower grain and stalk yield was found with $120 \mathrm{~cm}$ spacing (731 and $2471 \mathrm{~kg} \mathrm{ha}^{-1}$, respectively). Narrow row spacing had higher plant population $\left(74,074 \mathrm{ha}^{-1}\right)$ per unit area. Similar findings were also reported by Pavan et al., (2011).

Significantly higher yield components per plant were due to the total dry matter accumulation in plant. Significantly higher total dry matter production was found in 120 $\mathrm{cm}$ row spacing (66.72 $\mathrm{g} \mathrm{plant}^{-1}$ at harvest) 
compared to $90 \mathrm{~cm}$ row spacing $(62.04 \mathrm{~g}$ plant $\left.^{-1}\right)$. Significantly lower total dry matter accumulation was noticed in narrow row (60 $\mathrm{cm})$ spacing (55.20 $\left.\mathrm{g} \mathrm{plant}^{-1}\right)$. Similar findings were also reported by Jeevan Kumar et al., (2014)and Sarithaet al., (2012a). Importance of leaf area in relation to basic plant metabolic process such as photosynthesis is generally recognized. Differences in leaf area can affect plant spatial distribution and the microenvironment within population which plays a decisive role in the photosynthetic efficiency and light energy distribution of crops.

Significantly higher leaf area $\left(3465 \mathrm{~cm}^{2}\right.$ plant $^{-1}$ ) was recorded in $120 \mathrm{~cm}$ row spacing compared to $90 \mathrm{~cm}$ row spacing $\left(3121 \mathrm{~cm}^{2}\right.$ plant $\left.^{-1}\right)$. Significantly lower leaf area was found with narrow row $(60 \mathrm{~cm})$ spacing $(2830$ $\mathrm{cm}^{2}$ plant ${ }^{-1}$ ). Due to lesser availability of space in narrow row spacing $(60 \mathrm{~cm})$ there was competition for growth resources resulting in lesser leaf area compared to wider row spacing (90 and $120 \mathrm{~cm}$ ). Similar findings were reported by Chih-Li Yu et al., (2014).

The narrow row spacing recoded significantly higher plant height, leaf area index, leaf area duration and crop growth rate $(165.4 \mathrm{~cm}, 2.10$, 60.34 days and $2.39 \mathrm{~g} \mathrm{~m}^{-2}$ day $^{-1}$, respectively) compared to wider row spacing (90 and 120 $\mathrm{cm})$. Higher plant density brings certain morphological changes such as increase in plant height. Which might be due to more number of plants per unit area and also due to the reason that the sparsely sown crop spreads more than the closely spaced one which tends to grow in upright direction (Singh et al., 2012). Increases plant height is always advantageous from point of light interception. More light interception increase in dry matter production per unit area. Similar findings were reported by Chih-Li Yu et al., (2014) and Harinder Singh and Guriqbal Singh (2015).
Effect of varieties on growth, dry matter accumulation and yield

The variety, TTB-7 produced significantly higher grain and stalk yield (914 and $3427 \mathrm{~kg}$ $\mathrm{ha}^{-1}$, respectively) than BRG-2 (812 and 2986 $\mathrm{kg} \mathrm{ha}^{-1}$, respectively). The significantly higher yield in TTB-7 than BRG-2 was mainly due to significantly higher yield and growth components. The difference in grain yield of pigeonpea varieties was also reported by Prashanthi et al., (2001).

The pigeonpea variety TTB-7 recoded significantly higher plant height, number of branches per plant, leaf area per plant, leaf area index, leaf area duration, crop growth rate and total dry matter accumulation per plant (163.6 cm, 10.4, $3429 \mathrm{~cm}^{-2}$ plant $^{-1}, 1.81,50.97$ days, $2.33 \mathrm{~g} \mathrm{~m}^{-2}$ day $^{-1}$ and $65.33 \mathrm{~g} \mathrm{plant}^{-1}$, respectively) compared to BRG2.Photosynthetic capacity of plant depends upon the accumulation of photosynthates in leaves, leaf number and leaf area.

Effect of sowing dates on growth, dry matter accumulation and yield

The difference in pigeonpea grain and stalk yield (Table 1) due to sowing dates was significant. The May month sown pigeonpea recorded significantly higher grain $(1149 \mathrm{~kg}$ $\left.\mathrm{ha}^{-1}\right)$ and stalk yield (3721 $\left.\mathrm{kg} \mathrm{ha}^{-1}\right)$ than the June and July month sown pigeonpea.

Significantly lower grain and stalk yield recorded in July (538 and $2710 \mathrm{~kg} \mathrm{ha}^{-1}$, respectively) and June (901 and $3188 \mathrm{~kg} \mathrm{ha}^{-1}$, respectively) month sown pigeonpea.

May and June month sown pigeonpea were 113.53 and 67.45 per cent of grain yield, respectively than the July month sown. This was due to the higher value of yield and growth components. Rajput (1980) reported maximum seed yield with the crop sown on 
$10^{\text {th }}$ June as compared to $20^{\text {th }}$ and $30^{\text {th }}$ June recorded by several workers (Kumar et al., and $20^{\text {th }}$ July. Similar results were also 2008 and Rani and Raji Reddy, 2010).

Table.1 Growth and yield as influenced by row spacing, varieties and date of sowing in pigeonpea

\begin{tabular}{|c|c|c|c|c|c|c|c|c|c|}
\hline & $\begin{array}{l}\text { Plant } \\
\text { height } \\
(\mathrm{cm}) \text { at } \\
\text { harvest }\end{array}$ & $\begin{array}{l}\text { No. of } \\
\text { branches } \\
\text { per plant at } \\
\text { harvest }\end{array}$ & $\begin{array}{l}\text { Total dry matter } \\
\text { accumulation (g } \\
\left.\text { plant }^{-1}\right) \text { at harvest }\end{array}$ & $\begin{array}{l}\text { Leaf } \\
\text { area } \\
\left(\mathrm{cm}^{-2}\right. \\
\left.\text { plant }^{-1}\right) \\
\text { at } 120 \\
\text { DAS }\end{array}$ & $\begin{array}{l}\text { LAI at } \\
120 \\
\text { DAS }\end{array}$ & $\begin{array}{l}\text { LAD } \\
\text { (Days) at } \\
90-120 \\
\text { DAS }\end{array}$ & $\begin{array}{l}\text { CGR } \\
\left(\mathrm{g} \mathrm{m}^{-2}\right. \\
\left.\text { day }^{-1}\right) \\
\text { at } 90- \\
120 \\
\text { DAS }\end{array}$ & $\begin{array}{l}\text { Grain } \\
\text { yield } \\
\text { (kg ha } \\
\text { 1) }\end{array}$ & $\begin{array}{l}\text { Stalk } \\
\text { yield } \\
\text { (kg ha } \\
\text { 1) }\end{array}$ \\
\hline \multicolumn{10}{|c|}{ Row spacing (S) } \\
\hline $\mathrm{S}_{1}(60 \mathrm{~cm})$ & 165.4 & 8.2 & 55.20 & 2830 & 2.10 & 60.34 & 2.39 & 940 & 4089 \\
\hline$S_{2}(90 \mathrm{~cm})$ & 159.2 & 9.4 & 62.04 & 3121 & 1.54 & 43.05 & 2.10 & 918 & 3059 \\
\hline$S_{3}(120 \mathrm{~cm})$ & 152.4 & 10.3 & 66.72 & 3465 & 1.28 & 35.05 & 1.89 & 731 & 2471 \\
\hline S. Em. \pm & 2.2 & 0.2 & 2.45 & 87 & 0.05 & 1.26 & 0.14 & 15 & 126 \\
\hline C.D. @ 5\% & 6.3 & 0.7 & 6.95 & 246 & 0.15 & 3.58 & 0.39 & 43 & 356 \\
\hline \multicolumn{10}{|l|}{ Varieties (V) } \\
\hline $\mathrm{V}_{1}$ (TTB-7) & 163.6 & 10.4 & 65.33 & 3429 & 1.81 & 50.97 & 2.33 & 914 & 3427 \\
\hline $\mathrm{V}_{2}(\mathrm{BRG}-2)$ & 154.4 & 8.3 & 57.32 & 2849 & 1.47 & 41.33 & 1.92 & 812 & 2986 \\
\hline S. Em. \pm & 1.8 & 0.2 & 2.00 & 71 & 0.04 & 1.03 & 0.11 & 12 & 103 \\
\hline C.D. @ 5\% & 5.1 & 0.6 & 5.67 & 201 & 0.12 & 2.93 & 0.32 & 35 & 291 \\
\hline \multicolumn{10}{|c|}{ Date of sowing (D) } \\
\hline $\mathrm{D}_{1}$ & 185.2 & 10.7 & 71.26 & 4030 & 2.12 & 57.23 & 2.60 & 1149 & 3721 \\
\hline $\mathbf{D}_{2}$ & 160.8 & 9.6 & 61.20 & 2937 & 1.52 & 43.49 & 2.18 & 901 & 3188 \\
\hline $\mathbf{D}_{3}$ & 130.9 & 7.7 & 51.50 & 2449 & 1.27 & 37.72 & 1.59 & 538 & 2710 \\
\hline S. Em. \pm & 2.2 & 0.2 & 2.45 & 87 & 0.05 & 1.26 & 0.14 & 15 & 126 \\
\hline C.D. @ 5\% & 6.3 & 0.7 & 6.95 & 246 & 0.15 & 3.58 & 0.39 & 43 & 356 \\
\hline \multicolumn{10}{|c|}{ Row Spacing (S) x Varieties (V) x Date of sowing (D) } \\
\hline $\mathbf{S}_{1} \mathbf{V}_{1} \mathbf{D}_{1}$ & 204.9 & 10.9 & 67.24 & 4159 & 3.08 & 86.50 & 2.63 & 1284 & 4980 \\
\hline$S_{1} V_{1} D_{2}$ & 170.7 & 8.8 & 60.80 & 3047 & 2.26 & 63.83 & 2.92 & 1010 & 4504 \\
\hline$S_{1} V_{1} D_{3}$ & 132.7 & 7.3 & 50.30 & 2531 & 1.88 & 53.57 & 2.28 & 693 & 3726 \\
\hline$S_{1} V_{2} D_{1}$ & 186.7 & 8.2 & 60.46 & 3333 & 2.47 & 65.39 & 3.32 & 1165 & 4479 \\
\hline$S_{1} V_{2} D_{2}$ & 164.6 & 7.2 & 47.68 & 2085 & 1.54 & 48.34 & 1.70 & 964 & 3532 \\
\hline$S_{1} V_{2} D_{3}$ & 132.9 & 6.8 & 44.73 & 1828 & 1.35 & 44.41 & 1.48 & 526 & 3313 \\
\hline$S_{2} V_{1} D_{1}$ & 187.4 & 12.4 & 77.74 & 4161 & 2.05 & 56.67 & 2.73 & 1247 & 3833 \\
\hline$S_{2} V_{1} D_{2}$ & 164.9 & 9.8 & 66.52 & 3106 & 1.53 & 43.90 & 2.37 & 963 & 3280 \\
\hline$S_{2} V_{1} D_{3}$ & 142.5 & 8.9 & 56.15 & 2916 & 1.44 & 40.57 & 1.85 & 655 & 2768 \\
\hline$S_{2} V_{2} D_{1}$ & 170.5 & 8.5 & 65.93 & 4003 & 1.98 & 50.55 & 2.48 & 1170 & 3251 \\
\hline$S_{2} V_{2} D_{2}$ & 156.0 & 9.9 & 56.53 & 2644 & 1.31 & 36.84 & 2.07 & 919 & 2787 \\
\hline$S_{2} V_{2} D_{3}$ & 133.9 & 7.1 & 49.35 & 1893 & 0.94 & 29.79 & 1.07 & 552 & 2433 \\
\hline$S_{3} V_{1} D_{1}$ & 183.4 & 14.8 & 81.47 & 4280 & 1.59 & 43.53 & 2.23 & 1096 & 3017 \\
\hline$S_{3} V_{1} D_{2}$ & 158.7 & 12.0 & 74.83 & 3666 & 1.36 & 37.93 & 2.33 & 818 & 2772 \\
\hline$S_{3} V_{1} D_{3}$ & 126.8 & 8.4 & 52.88 & 2993 & 1.11 & 32.23 & 1.62 & 459 & 1958 \\
\hline$S_{3} V_{2} D_{1}$ & 178.6 & 9.2 & 74.71 & 4246 & 1.57 & 40.76 & 2.19 & 935 & 2767 \\
\hline$S_{3} V_{2} D_{2}$ & 150.2 & 10.1 & 60.84 & 3073 & 1.14 & 30.09 & 1.73 & 734 & 2253 \\
\hline$S_{3} V_{2} D_{3}$ & 116.6 & 7.6 & 55.61 & 2531 & 0.94 & 25.76 & 1.22 & 344 & 2060 \\
\hline S. Em. \pm & 5.4 & 0.6 & 6.00 & 212 & 0.13 & 3.09 & 0.34 & 37 & 308 \\
\hline C.D. @ 5\% & 15.3 & 1.7 & 17.02 & 602 & 0.36 & 8.78 & 0.96 & 104 & 874 \\
\hline
\end{tabular}

Note: $\mathrm{D}_{1}$ : May-28 $8^{\text {th }}$ and $30^{\text {th }}$ of 2015-16 and 2016-17, respectively; $\mathrm{D}_{2}$ : June-20 ${ }^{\text {th }}$ and $16^{\text {th }}$ of 2015-16 and 2016-17, respectively; $\mathrm{D}_{3}$ : July- $28^{\text {th }}$ and $29^{\text {th }}$ of $2015-16$ and $2016-17$, respectively. Interaction effect of row spacing $\mathrm{X}$ varieties, row spacing $X$ date of sowing and varieties $X$ date of sowing were non-significant 
The May sown pigeonpea recoded significantly higher plant height, number of branches per plant, leaf area per plant, leaf area index, leaf area duration, crop growth rate and total dry matter accumulation per plant $\left(185.2 \mathrm{~cm}, 10.7,4030 \mathrm{~cm}^{-2}\right.$ plant $^{-1}, 2.12$, 57.23 days, $2.60 \mathrm{~g} \mathrm{~m}^{-2}$ day $^{-1}$ and $71.26 \mathrm{~g}$ plant

1 , respectively) compared to June and July sown crop. Photosynthetic capacity of plant depends upon the accumulation of photosynthates in leaves, leaf number and leaf area. Dry matter accumulation is directly proportional to leaf area index (LAI). To obtain higher dry matter, photosynthetic efficiency of leaf area is very much essential.

\section{Interaction between row spacing, varieties and date of sowing $(S \times V \times D)$}

Interaction effect between row spacing, varieties and date of sowing found significant with grain and stalk yield (Table 1). Significantly higher grain yield (1284 kg ha-1) and stalk yield (4980 kg ha-1) was observed in narrow row spacing $(60 \mathrm{~cm})$ with TTB-7 variety at May month sown crop $\left(\mathrm{S}_{1} \mathrm{~V}_{1} \mathrm{D}_{1}\right)$ which was on par with $S_{2} V_{1} D_{1}, S_{1} V_{1} D_{2}$ and $\mathrm{S}_{1} \mathrm{~V}_{2} \mathrm{D}_{1}$. Significantly lower grain yield (344 $\mathrm{kg} \mathrm{ha}^{-1}$ ) was recorded in wider row spacing $(120 \mathrm{~cm})$ with BRG-2 at July sown crop $\left(\mathrm{S}_{3} \mathrm{~V}_{2} \mathrm{D}_{3}\right)$ and lower stalk yield (1932 $\left.\mathrm{kg} \mathrm{ha}^{-1}\right)$ was observed in wider row spacing $(120 \mathrm{~cm})$ with TTB-7 at July month sown crop $\left(\mathrm{S}_{3} \mathrm{~V}_{1} \mathrm{D}_{3}\right)$. Higher grain and stalk yield was due to more plant population from narrow row spacing with early sowing in the month of May along with TTB-7 variety. Similar trend were noticed in leaf area index, leaf area duration and crop growth rate.

Higher yield attributing character of pigeonpea is directly related on the total dry matter production (Table 1). Significantly higher total dry matter production $(81.47 \mathrm{~g}$ plant $^{-1}$ ) was observed with interaction effect of wider row spacing $(120 \mathrm{~cm})$ with May month sown pigeonpea and TTB-7 $\left(\mathrm{S}_{3} \mathrm{~V}_{1} \mathrm{D}_{1}\right)$. Significantly lower total dry matter production (44.73 g plant ${ }^{-1}$ ) was obtained from the narrow row spacing with July month sown pigeonpea and BRG-2 variety. Similar trend was observed in number of branches and leaf area per plant. The dry matter production and its accumulation in different parts depend upon the photosynthetic capacity of the plant at various growth stages. Photosynthetic capacity of plant depends upon the accumulation of photosynthates in leaves, leaf number and leaf area. The magnitude of photosynthetic ability of the crop is more meaningfully interpreted in terms of leaf area and number of branches per plant.

From the study it can be concluded that higher growth parameters, grain and stalk yield of pigeonpea was recorded in narrow row spacing with TTB-7 and May sowing.

\section{References}

Anonymous, 2016a, Agricultural Statistics at a glance. Visit at: www.agricoop. nic.in \& http:// eands.dacnet.nic.in

Chih-Li Yu, Dafeng Hui, Trevor Johnston, Kadijah Porter, Camerra Miller, Desh Duseja and Fisseha Tegegne, 2014, Field performance and yield of four pigeonpea varieties in middle Tennessee. Agron. J., 106(6): 22022208.

Donald, G. M., 1962, In search of yield. $J$. Australian Inst. Agric. Sci., 28:19711978.

Gomez, K. A. and Gomez, A. A., 1984, Statistical procedure for agricultural research. John Wiley and sons, New Delhi. Pp. 680.

Harinder Singh AND Guriqbal Singh, 2015, Growth, phenology and thermal indices of mungbean as influenced by sowing time, varieties and planting 
geometry. Indian J. Agric. Res., 49 (5): 472-475.

Jeevan Kumar, K., Balusamy, M. and Latha, K. R. 2014, Effect of plant geometry on the growth, yield and economics of rabi-pigeonpea (Cajanus cajan (L.) Millsp.). Int. J. Trop. Agric., 32 (34):509-511.

Kumar, N., Gopinath, K. A., Anil K. Srivastva and Vinay Mahajan, 2008, Performance of pigeonpea (Cajanuscajan (L.) Millsp.) at different sowing dates in the mid-hills of Indian Himalaya. Arch. Agron. Soil Sci., 54 (5): 507-514.

Pavan, A. S., Nagalikar, V. P., Pujari, B. T. and Halepyati, A. S., 2011, Influence of planting geometry on the growth characters, seed yield and economics of transplanted pigeonpea. Karnataka J. Agric. Sci., 24 (3): 390 - 392.

Prashanthi, L., Vasanthi, R. P. and Muneendra BABU, 2001, Evaluation of pigeonpea genotypes for rainfed conditions in the Southern Zone of Andhra Pradesh, India. Int. Chickpea and Pigeonpea News l., pp. 50-52.

Rajput, R. P., 1980, Response of soybean crop to climatic and soil environments. Ph.D. Thesis IARI, New Delhi, India.

Rani, B. P. and Raji Reddy, D., 2010, Performance of pigeonpea in sole and intercropping system in vertisols of Krishna - Godavari zone in Andhra Pradesh. Indian J. Agric. Res., 44 (3): $225-228$.

Saritha, K. S., Pujari, B. T., Basavarajappa, R., Naik M.K., Rameshbabu and Desai B. K., 2012a, Effect of irrigation, nutrient and planting geometry on yield, yield attributes and economics of pigeonpea. Karnataka J. Agric. Sci., 25 (1): 131-133.

Singh, S., Sandhu, S. K., Dhaliwal, L. K. and Singh, I., 2012, Effect of planting geometry on microclimate, growth and yield of mungbean (Vigna radiata $\mathrm{L}$.). J. Agric. Phys., 12:70-73.

\section{How to cite this article:}

Sharanappa Kuri, H.S. Shivaramu, M.N. Thimmegowda, S.B. Yogananda, S.S. Prakash and Murukannappa. 2018. Effect of Row Spacing, Varieties and Sowing Dates on Growth and Yield of Pigeonpea. Int.J.Curr.Microbiol.App.Sci. 7(08): 1125-1128. doi: https://doi.org/10.20546/ijcmas.2018.708.127 